\title{
EVALUASI KESESUAIAN PERESEPAN OBAT RAWAT JALAN TERHADAP FORMULARIUM OBAT PADA SALAH SATU PROVIDER ASURANSI KESEHATAN KOMERSIL DI BANDUNG
}

\author{
SUITABILITY EVALUATION FOR OUTPATIENT THE \\ PRESCRIPTION DRUG FORMULARY IN ONE PROVIDER \\ HEALTH INSURANCE COMMERCIAL IN BANDUNG
}

\author{
Eva Kusumahati ${ }^{1}$, Kusnandar Anggadiredja ${ }^{2}$, Lucy Lustiani ${ }^{3}$ \\ ${ }^{I}$ Farmasi Klinik dan Komunitas, FMIPA, Institut Teknologi Bandung \\ $\mathrm{Jl}$. Ganesa no 10 Bandung \\ ${ }^{2}$ FMIPA, Institut Teknologi Bandung \\ Jl.Ganesa no 10 Bandung \\ Email:evakusumahatiapt@gmail.com
}

\begin{abstract}
ABSTRAK
Penggunaan formularium obat di asuransi dapat menjamin standar peresepan yang berkualitas baik dan efisiensi biaya. Akan tetapi masih banyak provider yang menulis resep non formularium sehingga banyak keluhan obat dari peserta asuransi. Tujuan penelitian ini untuk mengidentifikasi dan menilai kesesuaian peresepan obat terhadap Formularium obat suatu asuransi. Penelitian ini merupakan penelitian observasi yang bersifat deskriptif analitik terhadap resep-resep yang datang di depo rumah sakit swasta di Bandung, khusus pasien sebagai peserta salah satu asuransi kesehatan komersil di Bandung. Analisis kuantitatif mengenai data untuk mengetahui persentase peresepan obat oleh dokter dilakukan berdasarkan berbagai kriteria diantaranya dari asal kunjungan poliklinik, jenis obat generik dan non generik, serta kesesuaian diagnosa dengan kelas terapi yang tercantum dalam formularium. Analisis kualitatif untuk mendeskripsikan kesesuaian antara resep dan pelayanan yang diberikan. Dari sejumlah 25 poliklinik yang ada di depo farmasi rawat sebanyak 15 poliklinik yang masih menuliskan obat non formularium. Sementara itu,obat generik yang diresepkan ada363 (42\%) dan obat non generik yang diresepkansebanyak 535 item obat $(58 \%)$. Berdasarkan sub kelas terapi obat, yang diperoleh daritotal 330 resep terdapat27 resep $(8 \%)$ obat non formularium, sedangkan yang sesuai dengan formularium obat asuransi sebanyak303 resep (92\%). Tinjauan terhadap kesesuaian penulisan resep dengan diagnosis menunjukkan $100 \%$ sesuai. Berdasarkan analisa kuantitatif menunjukkan masih ada $8 \%$ dari total 898 item obat diresepkan yang tidak sesuai dengan formulariumdan berdasarkan analisa kualitatif menunjukkan masih ada beberapa dokter yang menuliskan obat non formularium.
\end{abstract}

Kata kunci : kesesuaian penulisan resep, formularium obat, pasien rawat jalan, asuransi kesehatan komersil. 


\begin{abstract}
The use of drug formulary in insurance system can ensure a quality standard prescription and cost efficiency. However, many prescribers prescribe non-formulary drugs that cause inconvenience among the insurance participants. This study was aimed to identify and assess the compliance of prescriptions to an insurance formulary. This was an observational and descriptive study on prescriptions received at depot of a private hospital in Bandung, prescribed to participants of a commercial insurance company. Quantitative analyses to evaluate prescriber's prescription were carried out based on several criteria, including the polyclinic of origin, generic or non-generic and the suitability of diagnosis with therapeutic class listed in the formulary. Qualitative analyses assessed the prescription drugs which were filled. Prescription containing non-formulary drugs were found in 15 out of 25 polyclinics in the depot. Meanwhile, 363 (42\%) generic and 535 (58\%) non-generic items were prescribed. Based on sub-therapeutic class derived from 330 prescriptions, there were $27(8 \%)$ prescriptions containing non-formulary drugs, while those of formulary drugs were $303(92 \%)$ prescriptions. Review on the suitability of prescription with diagnosis showed $100 \%$ of conformity. Quantitative analyses showed that $8 \%$ out of 898 drug items did not belong to the formulary, while qualitative analyses revealed that some prescribers prescribed non-formulary drugs.
\end{abstract}

Key words: suitability of prescription, drug formulary, commercial health insurance

\title{
PENDAHULUAN
}

Pembangunan kesehatan bertujuan untuk meningkatkan derajat kesehatan yang optimal untuk seluruh masyarakat. Peningkatan kesehatan masyarakat dapat dicapai melalui berbagai upaya. Upaya kesehatan adalah setiap kegiatan untuk memelihara dan meningkatkan kesehatan yang dilakukan oleh pemerintah atau masyarakat yaitu melalui upaya kesehatan yang diselenggarakan dengan pendekatan pencegahan penyakit (preventif), penyembuhan penyakit (kuratif) pemeliharaan kesehatan (rehabilitatif), dan peningkatan kesehatan (promotif) yang dilakukan secara menyeluruh, terpadu, dan berkesinambungan (Depkes RI, 2009).

Salah satu upaya penyembuhan kesehatan yang dilakukan masyarakat dan pemerintah dalam menjamin kesehatan yaitu dengan diadakannya asuransi kesehatan. Asuransi kesehatan merupakan sistem pembiayaan kesehatan yang paling tepat untuk menjamin pemeliharaan kesehatan masyarakat. Pengaruh pelayanan kesehatan di Indonesia sangatlah besar, namun masih terdapat simpang siur terhadap system pembiayaan kesehatan yang berdampak pada pelayanan kesehatan. Kebijakan pembiayan kesehatan tidak sepenuhnya berada dalam kendali pemerintah, tingkat pendidikan, ekonomi dan sosial budaya yang semakin membaik secara relatif meningkatkan pemanfaatan pelayanan kesehatan. Dalam rangka meningkatkan mutu pelayanan kesehatan perlu menjamin aksesibilitas obat yang aman, berkhasiat, bermutu dan terjangkau dalam jenis dan jumlah yang cukup maka perlu disusun daftar obat dalam bentuk formularium (Kepmenkes RI, 2015).

Formularium adalah dokumen kumpulan obat dan informasi berkaitan, yang benarbenar dipertimbangkan staf professional, sebagai yang paling berguna dalam perawatan penderita. (Siregar,2004). Manfaat formularium obat asuransi merupakan pedoman dalam penyediaan dan pemberian obat-obatan bagi peserta asuransi pada seluruh tingkatan pelayanan mulai dari rawat jalan pertama, lanjutan sampai rawat inap untuk produk manage care (Inhealth, 2015).

Asuransi kesehatan komersil bekerjasama dengan instalasi farmasi rumah sakit dan apotek yang mempunyai tugas perencanaan, pengadaan, penyimpanan, penyiapan, peracikan, pelayanan langsung kepada penderita dan pengendalian semua perbekalan kesehatan di dalam rumah sakit, klinik, dokter keluarga dan dokter gigi. Berkaitan dengan 
tugas tersebut, asuransi kesehatan dan instalasi farmasi rumah sakit harus menyediakan obat yang optimal bagi semua penderita, menjamin pelayanan bermutu tinggi, yang paling bermanfaat dengan biaya minimal (Depkes RI, 2014).

Pada umumnya rumah sakit atau pihak asuransi kesehatan memiliki suatu formularium atau daftar obat, tetapi pemanfaatan formularium tersebut sebagai salah satu alat untuk meningkatkan efisiensi pemanfaatan obat masih belum optimal (Anggriani, 2008). Berdasarkan Permenkes RI no 58 tahun 2014, Untuk menjamin mutu pelayanan kefarmasian maka harus dilakukan evaluasi kesesuian peresepan obat terhadap formularium obat asuransi yang diteliti.

Dengan adanya formularium obat asuransi yang diteliti dan penulisan resep obat yang dilakukan oleh provider akan menimbulkan potensi penulisan obat non formularium. Oleh karena itu,perlu dilakukan identifikasi untuk menilai kesesuaian peresepan obat rawat jalan terhadap formularium obat asuransi yang diteliti.

Berdasarkan studi pendahuluan yang telah dilakukan pada bulan Juli sampai dengan September 2015, diketahui dari 16 provider farmasi rumah sakit yang bekerjasama dengan asuransi, hanya ada satu provider yang mempunyai peningkatan beban klaim dan kunjungan terbesar yaitu sebesar 2\% tiap bulan pada rawat jalan. Provider inilah yang berpotensi ketidaksesuaian penulisan resep non formularium. Dengan adanya standar formularium diharapkan dokter dapat mematuhi secara konsisten dalam peresepan obat sesuai formularium yang telah ditetapkan oleh asuransi tersebut. Selain itu dalam penelitian ini untuk mengidentifikasi dan menilai kesesuaian obat dalam resep terhadap formularium obat asuransi kesehatan komersil, di salah satu rumah sakit swasta di kota Bandung.

Penelitian ini merupakan penelitian yang baru dilakukan dalam menilai kesesuaian terhadap formularium obat salah satu asuransi kesehatan swasta di Bandung, penelitian kebanyakan mengevaluasi kesesuaian peresepan obat terhadap formularium rumah sakit dan formularium nasional.

\section{METODE PENELITIAN}

Penelitian ini merupakan penelitian observasional, pengambilan data secara retrosfektif terhadap resep-resep yang telah diklaimkan provider kepada verifikator asuransi, untuk dilakukan evaluasi terhadap variabel penelitian berdasarkan poliklinik, generik atau non generik, kesesuaian diagnose dengan sub kelas terapi yang ada dalam formularium obat asuransi yang diteliti.

\section{Desain Penelitian}

Tahapan pertama dilakukan study pendahuluan secara retrospektif dari bulan Juli sampai September 2015 pada aplikasi online asuransi yang diteliti untuk menentukan provider target penelitian berdasarkan jumlah kunjungan dan biaya terbesar dan jumlah sampel resep yang diteliti.

Tahap kedua dilakukan penelitian dari bulan Oktober sampai Desember 2015, mulai mengamati dari resep-resep, untuk mengevaluasi variabel penelitian berdasarkan poliklinik, , kesesuaian diagnose dengan sub kelas terapi yang ada dalam formularium obat asuransi yang diteliti.Pengumpulan data dilakukan dengan metode random sampling, kemudian pengolahan data menggunakan metode stratified random sampling

Tahap ketiga dilakukan analisa secara kuantitatif untuk mengetahui pola peresepan obat oleh dokterdan kualitatif untuk mendeskripsikan kesesuaian antara resep obat dan pelayanan yang diberikan, sehingga dapat diketahui persentase jumlah peresepan obat rawat jalan yang sesuai dan tidak sesuai dengan formularium obat asuransi yang diteliti lalu disajikan secara deskriptif. 


\section{HASIL DAN PEMBAHASAN}

Sampel yang diambil dengan menggunakan metode random sampling dengan menggunakan rumus slovin sebagai acuan, nilai alfa yang dipakai adalah 0,05 , sebanyak 330 lembar resep (Tabel.I). Setelah didapatkan data yang sebenarnya selanjutnya dilakukan pengolahan data dengan menggunakan metode stratified random sampling, dimana dari 330 lembar resep tersebut diklasifikasikan berdasarkan masing-masing jenis poliklinik yang ada di rawat jalan. Berikut klasifikasi resep berdasarkan poliklinik.

Tabel I. Distribusi Sampel yang diambil Berdasarkan Poliklinik

\begin{tabular}{lccc}
\hline Poliklinik & $\begin{array}{c}\text { Jumlah } \\
\text { Lembar } \\
\text { Resep }\end{array}$ & $\begin{array}{c}\text { Persentase } \\
\mathbf{( \% )}\end{array}$ & $\begin{array}{c}\text { Jumlah } \\
\text { Sampel }\end{array}$ \\
\hline Anak & 143 & $7,55 \%$ & 25 \\
Bedah digestif & 6 & $0,32 \%$ & 1 \\
Bedah onkologi & 6 & $0,32 \%$ & 1 \\
Bedah orthopedi & 81 & $4,28 \%$ & 14 \\
Bedah umum & 34 & $1,80 \%$ & 6 \\
Bedah urologi & 17 & $0,90 \%$ & 3 \\
Dalam & 545 & $28,79 \%$ & 95 \\
Fisioterapi & 75 & $3,96 \%$ & 13 \\
dan rehabilitasi medik & 11 & $0,58 \%$ & 2 \\
Gastro & 63 & $3,33 \%$ & 11 \\
Gigi & 98 & $5,18 \%$ & 17 \\
Jantung & 126 & $6,66 \%$ & 22 \\
Kulit kelamin & 6 & $0,32 \%$ & 1 \\
Laboratorium & 126 & $6,66 \%$ & 22 \\
Mata & 92 & $4,86 \%$ & 16 \\
Obgyn & 40 & $2,11 \%$ & 7 \\
Paru & 11 & $0,58 \%$ & 2 \\
Radiologi & 63 & $3,33 \%$ & 11 \\
Saraf & 172 & $9,09 \%$ & 30 \\
THT & 172 & $9,09 \%$ & 30 \\
UGD & 6 & $0,32 \%$ & 1 \\
Umum & 0 & 0 & 0 \\
Jiwa & 0 & 0 & 0 \\
Gizi & 0 & 0 & 0 \\
Hemodialisa & \multicolumn{1}{c}{ Jumlah } & $100 \%$ & 330 \\
\hline & & & \\
\hline & 1893 & \\
\hline
\end{tabular}

Keterangan : Data yang diambil merupakan peresepan obat selama periode bulan Oktober Desember 2015 hanya untuk pasien asuransi yang diteliti. 
Dari 27 peresepan non-formularium (Tabel.III), yang terbanyak diresepkan adalah multivitamin sebanyak10 kali peresepan, antivertigo 5 kali, anti Tuberkulosis 4 kali, antiagregasi platelet dan mukolitik ekspektoran masing-masingsebanyak 2 kali. Sedangkan sisanya 1 kali peresepan masing-masing untukantibiotik gololngan makrolida, antitukak, anti emetik, psikotropik.Aspek kesesuaian peresepan obat dengan diagnose terhadap kelas terapi dilihat dari surat jaminan pelayanan terhadap formularium obat sudah sesuai literature. Hasil pengkajian aspek kesesuian adalah $100 \%$, artinya tidak ada masalah penulisan resep obat dengan diagnose terhadap kelas terapi dalam formularium obat asuransi yang diteliti.

Berdasarkan analisa kualitatif secara konkuren, ditemukan ketidak sesuaian antara diagnose dan peresepan obat terutama pada saat input data, sebagai contoh di poli jantung dengan diagnose CHF (Congestive Heart Failure), 1 resep yang menuliskan clopidogrel, penyerahan obat trombikaf, diinput thrombureduktin yang harganya lebih mahal. Tahap peresepan sampai penyerahan obat kepada pasien sudah sesuai tetapi pada saat provider menginput data untuk klaim kepada asuransi yang diteliti terjadi kesalahan penginputan nama obat, hal ini berpotensi pada penambahan beban pembayaran klaim asuransi yang diteliti kepada provider mitra. Kasus kesalahan yang paling beresiko adalah tahap entri data sebesar $0,3 \%$ (1 resep) dari 330 resep, untuk mengatasinya maka diperlukan perhatian dari berbagai pihak dalam mencegah kesalahan.

\section{Tabel II. Jumlah Peresepan Obat Non Formularium Berdasarkan Poliklinik}

\begin{tabular}{lc}
\hline Nama Poliklinik & $\begin{array}{c}\text { Jumlah Peresepan Obat } \\
\text { Non Formularium } \\
\text { (Total=330 lembar resep) }\end{array}$ \\
\hline UGD (unit gawat darurat) & 1 \\
Anak & 2 \\
Kulit dan kelamin & 6 \\
Obgyn & 3 \\
Dalam & 4 \\
Bedah orthopedic & 1 \\
Bedah onkologi & 1 \\
Saraf & 2 \\
THT (telinga hidung tenggorokan) & 1 \\
Mata & 1 \\
Bedah umum & 1 \\
Bedah urulogi & 1 \\
Gigi & 1 \\
Jantung & 1 \\
Bedah digestif & Jumlah \\
\hline
\end{tabular}

Berdasarkan statistik deskriptif (Tabel. III), menggambarkan ketidak sesuaian peresepan obat terhadap formularium obat sebesar $8,1 \%$ dalam hal non formularium. hasil observasi, wawancara dan bukti penolakan dari pedagang besar farmasi, maka faktor penyebab ketidak sesuaian diantaranya dikarenakan obat kosong, kurang faktur pada saat order obat, perbedaan jenis pabrikan yang ada di depo dengan yang tercantum dalam 
formularium, perbedaan kekuatan obat yang ada di depo dengan yang tercantum dalam formularium obat. Meskipun jumlahnya memang cukup kecil hanya sebesar 8,1\% (27 peresepan obat) dari total 330 peresepan obat oleh dokter, namun tetap saja masih ada saja dokter yang menuliskan obat non formularium.

Tabel III. Jumlah Peresepan Obat Formularium dan Non Formularium

\begin{tabular}{ccc}
\hline Keterangan & $\begin{array}{c}\text { Resep } \\
\text { Formularium }\end{array}$ & $\begin{array}{c}\text { Resep Non } \\
\text { Formularium }\end{array}$ \\
\hline $\begin{array}{c}\text { Jumlah Resep } \\
\text { (total=330 resep) }\end{array}$ & 303 & 27 \\
\hline Persentase (\%) & 91,8 & 8,1 \\
\hline
\end{tabular}

\section{KESIMPULAN}

Analisa kuantitatif menunjukkan bahwa dari 25 poliklinik ada 15 poliklinik yang masih menuliskan obat non formularium. Berdasarkan sub kelas terapi obat, didapatkan hasil sub kelas terapinya ada 27 resep (8\%) obat non formularium, sedangkan yang sesuai dengan formularium obat asuransi sebanyak 303resep (92\%). Kesesuaian diagnosa dengan kelas terapi sebesar $100 \%$.berdasarkan analisa kualitatif menunjukkan masih ada beberapa dokter yang menuliskan obat non formularium

\section{DAFTAR PUSTAKA}

Anggriani, Y.,dkk.2008. Pengaruh Proses Revisi dan Pengembangan Formularium Rumah Sakit Terhadap Pengadaan dan Stok Obat, Jurnal Ilmu Kefarmasian Indonesia, UGM, Yogyakarta.

Aprillia, E. 2012. Motivasi Dokter Dalam Penulisan Resep di Rumah Sakit Risa Sentra Medika, FKM UI, Depok.

Brown, T. R.1992. Handbook of Institutional Pharmacy Practice, 3th ed., American Society of Hospital Pharmacist inc., Bethesda. 165, 215.

Dharma, K. 2011. Metodologi Penelitian Kesehatan. Trans Info Media, Jakarta, 104, 180228.

Depkes RI. 2014. Peraturan Menkes RI No. 58 tahun 2014 tentang Standar Pelayanan Kefarmasian di Rumah Sakit.

Depkes RI. SK Menkes RI No. 129/Menkes/SK/II/2008 tentang Standar Pelayanan Minimal Rumah Sakit, 38.

Depkes RI. 2009. Undang-Undang Republik Indonesia No. 44 tentang Rumah Sakit.

Health Care Team Inhealth. 2015. Modul Claim Management Pelaporan dan Analisa Data. PT Solusi Profesional Medika Indonesia. Jakarta.

Hicks, W. E. 1994 Practice Standard of ASHP. The American Society of Hospital Pharmacists Inc, Bethesda, 55, 191.

http://indonesia-community.co.iddiakses tanggal 29 Februari 2016.

Inhealth. 2010. Keputusan Direktur no 316/Kep/0410 tentang Pedomana Pelayanan Kesehatan Inhealth Managed Care. Jakarta.

Iskandar, K. 2011. Dasar-Dasar Asuransi Jiwa, Kesehatan dan Annuitas. AAMAI (Asosiasi Ahli Manajemen Asuransi Indonesia) Jakarta, 34.

Depkes RI. 2009. Keputusan Menteri Kesehatan Republik Indonesia Nomor 44 Tahun 2009 Tentang Rumah Sakit.

Mandiri Inhealth. 2011. e-learning Mandiri Inhealth. Jakarta

Mandiri Inhealth. 2014 Formularium Obat Inhealth Edisi IV. Jakarta 
Mandiri Inhealth. 2015 Edisi VII :Formularium Obat Inhealth Edisi VII. Jakarta

Menkes RI. 2015. Kepmenkes RI no HK.02.02/MENKES/523/2015 tentang Formularium Nasional. Jakarta

Pamjaki. 2011. Modul Dasar-dasar Asuransi Kesehatan komersil. Jakarta.

Peraturan Pemerintah Republik Indonesia Nomor 124/ Menkes/ SK/ LI/ 2009.

Phase. 2013. Booklet when SJSN comes into Reality. Sidang UI. Depok, 13.

Peterson, A. M. 2004 :Managing Pharmacy Practice.America : CRC Press LLC, 183.

Puspita, dkk.2014. Evaluasi Kesesuaian Resep dengan Formularium pada Pasien Umum Rawat Jalan di RSUD Kota Magelang. Tesis UGM.

Rahmah, A.N. 2011. Modul Peningkatan Kompetensi Pelayanan Kesehatan. Bandung, 2-11.

Siregar, C. J. P., dan Kumolosasi, E. (2005) :Farmasi Klinik Teori dan Penerapan. Penerbit Buku Kedokteran EGC. Jakarta. Bab VI, 87. Bab IX. Hal, 188. Bab XXI, 592.

Siregar, C. J. P., dan Lia, A. 2004. Farmasi Rumah Sakit Teori dan Penerapan. Penerbit Buku Kedokteran EGC. Jakarta. Bab VI, 66, dan Bab VII, 88.

Wambrau, J. 2006. Analisa faktor-faktor yang Mempengaruhi Ketidakpatuhan Dokter Dalam Penulisan Resep Sesuai Dengan Formularium Rumah Sakit Umum R.A. KARTINI Jepara, UNDIP, Semarang. 